\title{
PERBANDINGAN SHUTTLE RUN EXERCISE DAN LADDER DRILL EXERCISE TERHADAP KELINCAHAN PADA PEMAIN FUTSAL
}

\author{
Putu Maryansyah Indra Fahlefi, Ali Multazam, Safun Rahmanto, \\ Anita Faradilla Rahim* \\ Departement Fisioterapi, Universitas Muhammadiyah Malang, Jalan Bandung No. 1Malang 65133 \\ *Corresponding author: anitafaradilla@umm.ac.id
}

\begin{abstract}
ABSTRAK
Kelincahan merupakan salah satu komponen fisik yang harus dimiliki oleh setiap pemainnya, namun saat ini banyak ditemukan pemain yang memiliki kelincahan dengan kategori rendah, terutama saat bergerak, menggiring bola dan dalam melewati lawan lawannya. Latihan yang dapat digunakan untuk meningkatkan kelincahan pada pemain futsal adalah Shuttle Run Exercise dan Ladder Drill Exercise. Tujuan Penelitian ini untuk mengetahui apakah terdapat perbedaan pengaruh Shuttle Run Exercise dan Ladder Drill Exercise Terhadap Peningkatan Kelincahan pada Pemain Futsal. Desain penelitian menggunakan pre-eksperimental dengan two group pretest and post test design untuk pengetahui perbandingan Shuttle Run Exercise dan Ladder Drill Exercise terhadap kelincahan pemain futsal yang dilakukan pada 30 orang pemain futsal selama kurun waktu 4 minggu. Instrument penelitian yang digunakan adalah Illinois Agility Test. Berdasarkan uji normalitas menunjukkan data tidak normal. Hasil uji Willxocon memiliki hasil yang sama yaitu ( $\mathrm{p}=0,01)$, Hasil uji Mann-Whitney Test $(\mathrm{p}=0,139)$. Latihan yang dilakukan selama 4 minggu menunjukkan tidak terdapat perbandingan yang signifikan antara Shuttle Run Exercise dan Ladder Drill Exercise terhadap kelincahan pada pemain futsal.
\end{abstract}

\section{Keywords: Kelincahan, Shuttle Run Exercise, Ladder Drill Exercise}

\section{PENDAHULUAN}

Futsal merupakan sebuah olahraga modifikasi dari sepakbola dimana futsal hanya dimainkan oleh beberapa orang serta lapangan yang lebih kecil (Prakoso, 2013). Futsal merupakan sebuah cabang olahraga yang memerlukan taktik di dalam permainannya salah satunya menggiring bola (Dewi, 2015). Menggiring bola merupakan teknik dasar dalam futsal, pemain futsal juga di tuntut dapat melewati lawannya yang dimana kedua teknik tersebut sangat dipengaruhi oleh kelincahan. Kelincahan adalah kemampuan seseorang memperlambat, mempercepat, bahkan merubah gerakan tanpa kehilangan keseimbangan (Tollison, 2011).

Kelincahan sangat berperan dalam permainan futsal, maka dari itu sudah sepantasnya pemain futsal memiliki kelincahan dalam bergerak dan menggiring bola serta kelincahan dapat menghindari pemain dari risiko cidera. Namun pada kenyataannya di lapangan masih banyak ditemui pemain yang kurang dalam kelincahannya terutama saat bergerak, menggiring bola dan dalam melewati lawan lawannya. Apabila kelincahan dalam bergerak dan menggiring bola dapat di kuasai oleh pemain tersebut maka ada kemungkinan tim tersebut mendapat banyak keuntungan mulai dari saat 
menyerang hingga lebih mudah melewati lawannya (Mashud, 2016).

Salah satu metode untuk melatih kelincahan adalah dengan shuttle run. Shutlle run exercise memiliki tujuan yaitu untuk meningkatkan kemampuan kelincahan dimana pemain dituntut untuk lari bolak-balik secepatnya diawali dari satu titik kemudian berlari ke titik lainnya dalam jarak yang telah diatur (Teixeira, 2019). Unsur pergerakan didalam latihan ini adalah lari kencang kemudian merubah posisi serta arah tubuh (Rahman, 2018).

Selain shuttle run, ada juga jenis latihan yang bertujuan untuk meningkatkan kelincahan seseorang yaitu ladder drill exercise. Ladder drills adalah suatu jenis latihan yang menggunakan media berbentuk tangga yang di letakkan di atas permukaan lantai, lapangan atau tanah yang bertujuan untuk melatih kelincahan otot dibagian kaki. Ladder drill merupakan latihan yang paling sering di lakukan diberbagai dunia karena latihan ini dapat membantu pemain dalam berbagai jenis dan macam gerak yang dapat meningkatkan kelincahan dan kecepatan dengan koordinasi yang lebih baik. Selain itu pada latihan ini bisa mengajarkan seorang pemain supaya mengambil langkah-langkah yang tepat sesuai kelincahannya (Hadi, 2016).

\section{METODE}

Metode pada penelitian yang peneliti gunakan ialah metode quasi eksperimental pre-test and post-test two group design yang meneliti hubungan sebab-akibat antar dua variabel dependent dan variabel independent dalam waktu yang telah di tentukan. Jumlah Populasi dalm penelitian ini sebanyak 50 orang dan yang masuk sampel sebanyak 30 orang. Pengukuran kelincahan menggunakan Illinois Agility Test. Uji normalitas pada penelitian ini mempergunakan uji Shapiro Wilk, uji pengaruh yang digunakan adalah wilcoxon singed rank test untuk menguji hipotesis dimana datanya berpasangan dan hasil uji normalitasnya mendapatkan nilai tidak normal dan Uji beda pengaruh yang digunakan adalah uji mann whitney.

\section{HASIL PENELITIAN}

1. Karakteristik Responden Berdasarkan Usia

Tabel 1 Usia Responden

\begin{tabular}{ccc}
\hline Usia & Persentase & Jumlah \\
\hline 17 tahun & 6 & 2 \\
18 tahun & 17 & 5 \\
19 tahun & 23 & 7 \\
20 tahun & 23 & 7 \\
21 tahun & 7 & 2 \\
22 tahun & 10 & 3 \\
24 tahun & 7 & 2 \\
25 tahun & 7 & 2 \\
\hline
\end{tabular}

Berdasrkan tabel di atas sebaran sampel penelitian berkisar usia 17-25 tahun, dimana usia 17 tahun sejumlah 2 responden (6\%), usia 18 tahun sejumlah 5 responden (17\%), usia 19 tahun sejumlah 7 responden $(23 \%)$, usia 20 tahun sejumlah 7 responden (23,\%), usia 21 tahun sejumlah 2 responden $(7 \%)$, usia 22 tahun sejumlah 3 responden (10\%), usia 24 tahun sejumlah 2 responden $(7 \%)$ dan usia 25 tahun sejumlah 2 responden $(7 \%)$

2. Karakteristik Responden berdasrkan IMT

Berikut ini merupakan tabel karakteristik responden berdasarkan indek masa tubuh (IMT)

Tabel 2 IMT Responden

\begin{tabular}{ccc}
\hline IMT & Persentase & Jumlah \\
\hline Normal & 68 & 20 \\
Pre Obes & 32 & 10 \\
\hline
\end{tabular}

Berdasarkan tabel diatas terdapat beberapa kategori penggolongan indeks masa tubuh. Menurut WHO asian-BMI classification yang di publikasikan tahun 2009 terdapat beberapa kategori pembagian kategori IMT didalam penelitian ini sebanyak 20 orang pada kategori normal (68\%) 
dan 10 orang pada kategori pre obesity $(32 \%)$.

3. Karakteristik responden berdasarkan nilai kelincahan sesudah dan sebelum diberikan intervensi shuttle run dan ladder drill.

Berikut ini merupakan nilai rata rata kelincahan responden sebelum dan sesudah diberi intervensi

Tabel 3 Rata - Rata Nilai

\begin{tabular}{cccc}
\hline Latihan & Pre & Post & Selisih \\
\hline Shuttle Run & 17,46 & 16,77 & 0,69 \\
Ladder Drill & 17,74 & 17,18 & 0,56 \\
\hline
\end{tabular}

Dari tabel rata - rata di atas dapat diidentifikasikan perubahan kelincahan 30 responden sebelum diberi dan sesudah diberi intervensi. Rata - rata kelincahan pada kelompok latihan shuttle run sebelum diberi intervensi adalah 17,46 dan setelah diberikannya intervensi sebesar 16,77 dengan selisih 0,69. Sedangkan untuk kelompok latihan ladder drill sebelum diberi intervensi adalah 17,74 dan sesudah diberi intervensi adalah 17,17 dengan selisih 0,56.

4. Uji Normalitas

Berikut hasil uji normalitas yang dimana menggunakan uji shapiro-wilk dengan sapel sebanyak 30 orang responden.

Tabel 4 Uji Normalitas

\begin{tabular}{ccc}
\hline \multirow{2}{*}{ Kelompok } & \multicolumn{2}{c}{ Nilai Sig. 2 Tailed } \\
\cline { 2 - 3 } & Pre test & Post test \\
\hline $\begin{array}{c}\text { Shuttle Run } \\
\text { Exercise }\end{array}$ & 0,046 & 0,047 \\
\hline $\begin{array}{c}\text { Ladder Drill } \\
\text { Exercise }\end{array}$ & 0,044 & 0,031 \\
\hline
\end{tabular}

Dari hasil uji normalitas pada tabel yang dijabarkan diatas memperlihatkan hasil significant pre-post shuttle run exercise 0,046 dan 0,047 sedangkan untuk pre-test dan post-test ladder drill exerecise adalah 0,044 dan 0,031. Berdasarkan hasil uji normalitas diatas disimpulkan bahwa data tersebut terdistribusi tidak normal, hal tersebut dikarenakan nilai $\alpha$ lebih kecil dari 0,05
5. Pengaruh Shuttle Run Exercise Terhadap Kelincahan Pemain Futsal

Tabel 5 hasil uji wilxocon kelompok shuttle run

\begin{tabular}{ccc}
\multicolumn{3}{c}{ Shuttle run } \\
\hline Kelompok & $\mathrm{n}$ & Sig.2-tailed \\
\hline Shuttle Run & 15 & 0,001 \\
\hline
\end{tabular}

Berdasarkan tabel 5 hasil uji Wilcoxon pada kelompok latihan shuttle run exercise diperoleh nilai signifikansi sebesar 0,001 yang berarti lebih kecil dari nilai $\alpha \quad 0,05$. Kesimpulan dari data di atas terdapat pengaruh pemberian latihan shuttle run terhadap kelincahan pemain Futsal.

6. Pengaruh Ladder Drill Exercise Terhadap Kelincahan Pemain Futsal

Tabel 6 Hasil Uji wilxocon Kelompok Ladder Drill Exercise

\begin{tabular}{ccc} 
Kelompok & $\mathrm{n}$ & Sig.2-tailed \\
\hline Ladder Dril & 15 & 0,001 \\
\hline
\end{tabular}

Berdasarkan tabel 6 yang merupakan hasil dari uji Wilcoxon pada kelompok latihan ladder drill exercise diperoleh nilai signifikansi 0,001 yang berarti lebih kecil dari nilai $\alpha 0,05$. Kesimpulan dari tabel diatas terdapat pengaruh latihan ladder drill terhadap nilai kelincahan pemain Futsal

7. Perbandingan Efektifitas Shuttle Run Exercise dan Ladder Drill Exercise Terhadap Kelincahan pemain Futsal

Tabel 7 Hasil uji Mann-Whitney Test

\begin{tabular}{lcc}
\hline & $\mathrm{n}$ & Sig.2-Tailed \\
\hline Perbandingan & & \\
Pengaruh & & \\
Shuttle Run & 30 & 0,139 \\
Exercise dan & & \\
Ladder Drill & & \\
$\quad$ Exercise & & \\
\hline
\end{tabular}

Berdasarkan tabel 7 menunjukkan jumlah sampel secara keseluruhan sebanyak 30 orang. Hasil perbandingan pengaruh latihan menggunkan uji 
pengaruh mann-whitney test diperoleh nilai $0,139>\alpha=0,05$. Maka dapat disimpulkan bahwa $\mathrm{H} 1$ ditolak dan $\mathrm{H} 0$ diterima, yang dapat diartikan tidak adanya perbedaan pengaruh yang signifikan antara latihan shuttle run dan ladder drill teradap kelincahan pemain Futsal.

\section{PEMBAHASAN}

Pada saat berusia 20 tahun terdapat pembentukan tulang yang kuat dan pesat, dimana remaja pada usia tersebut mengalami persiapan untuk mencapai masa peak grouth of bone. Masa tulang inilah yang akan mempengaruhi kelincahan seorang pemain (Meng, 2014). Kelincahan seseorang akan bertambah hingga mencapai usia pendewasaan (Utama, 2013). Menurut Paul (2015) kelincahan seseorang akan bertambah hingga berusia 25 tahun, kemudian setelah itu akan terjadinya penurunan dari kapasitas fungsional pada tubuh berkisar 0,8 sampai $1 \%$ pertahun. Hal tersebut serupa dengan sebuah penelitian yang dilaksanakan oleh Mahendra (2015) dimana pada penelitiannya yang memiliki judul relationship between body mass index and agility of 19-24 year old male futsal player menyatakan bahwa pemain yang berusia 19 sampai 24 tahun memiliki pertumbuhan mental dan fisik yang lengkap

Indeks masa tubuh atau disingkat IMT merupakan hasil perhitungan antara berat badan seseorang dalam satuan $\mathrm{kg}$ kemudian dibagi tinggi badan seseorang menggunakan satuan meter pangkat dua dengan rumus $\mathrm{BB} / \mathrm{TB}^{2} \quad\left(\mathrm{~kg} / \mathrm{m}^{2}\right)$ (Kemenkes, 2013). Peningkatan berat badan dan endomorph pada responden dapat menurunkan performa subjek dalam kelincahan dan dribbling bola (Taghinejad, 2013).

Penelitian yang dilakukan Dhapola (2017) berpendapat bahwa semakin besar berat badan seorang atlet maka semakin besar beban yang dibawa atlet saat bergerak sehingga hal ini berpengaruh terhadap penurunan kelincahan seorang atlet. Seseorang yang memiliki berat badan berlebih juga berpengaruh terhadap hambatan dan pergerakan keleluasaan gerak sendi yang diakibatkan kontak langsung dengan bagian tubuh yang lain (Putra dkk., 2016).

Berat badan yang berlebih secara langsung akan mengurangi kelincahan, dimana berat badan berlebih cenderung mengakibatkan muscle imbalance di bagian trunk kuga adanya friksi jaringan lemak pada serabut otot sehingga kontraksi otot menjadi berkurang (Untoro, 2017)

Mengubah arah gerak tubuh dengan berulang ulang layaknya latihan shuttle run memerlukan kontraksi secara silih berganti pada bagian grup otot tertentu. Sebagaimana contohnya saat melakukan lari bolak-balik pemain tersebut diharuskan mengurangi kecepatannya dan kemudian berubah arah. Untuk itu otot yang berada di hip dan knee akan mengalami kontraksi eksentrik, saat otot melambat postur tubuh akan bergerak ke arah depan. Lalu dengan sigap dan cepat otot-otot akan memacu ke posisi tubuh yang baru untuk selanjutnya berlagi ke titik awal (Budiawan, 2014)

Berdasrkan penelitian yang dilakuakan oleh Baruna (2018), Shuttle Run efektif dalam meningkatkan kelincahan dikarenakan saat melaksanakan latihan tubuh seseorang mengalami adaptasi dari fisiologinya. Pada saat pemberian latihan secara teratur dapat menyebabkan terjadinya hyper tropy pada fisiologi otot. Terjadinya hyper tropy pada otot disebabkan karna bertambah besar jumlah myofibril didalam serabut otot dan meningkatkan kepadatan kapiler didalam serabut otot. Peningkatan serabut otot terjadi pada bagian fast twitch atau biasa disebut dengan seabut otot putih, ini mengakibatkan terjadi penaikan kecepatan dalam berkontraksi otot. Dengan terjadinya penambahan kecepatan dalam mengkontraksikan otot maka akan menyebabkan peningkatan kelincahan pada pemain (Womsiwor, 2014). 
Menurut penelitian yang dilakukan Rakhmawati (2019) Shuttle run dapat meningkatkan kelincahan seseorang karena dalam latihan tersebut dengan melakukan latihan shuttle run secara sistematis serta dilakukan secara terus secara berulang ulangdengan durasi yang lama dapat meingkatkan kerja serta aktivitas pada mitokondria didalam sel otot. Pada setiap pertemuan diberi satu latihan yang sama menimbulkan adaptasi dari tubuh terhadap effek shuttle run exercise yang diberikan dapat meningkatkan kelincahan.

Berdasarkan sebuah penelitian yang dilakukan oleh Chandrakumar dan Ramesh (2015) yang memiliki judul Effect ladder drills and $S A Q$ training on agility and speed among sport badminton club player bahwa ladder drill exercise dapat meningkatkan kelincahan karena dalam latihan tersebut dapat meningkatkan reaksi dan sistem neuromuscular. Adaptasi neuromuscular terjadi karena ada peningkatan presentasi aktivasi motor unit. Ladder dill exercise menyebabkan peningkatan koordinasi, kecepatan, kelincahan kaki dan peningkatan konduktivitas saraf sehingga berdampak pada peningkatan koordinasi neuromuscular. Dengan meningkatnya koordinasi neuromuscular, dapat menpengaruhi dari kecepatan reaksi yang ada pada tungkai, kemudian dapat membentuk efektifitas serta efisiensi dari gerakan tungkai.

Penelitian yang dilakukan oleh Kusnatik (2017) dimana dengan diberikannya latihan ladder drill otot-otot diharapkan menjadi lebih elastis serta ruang pergerakan sendi menjadi lebih baik sehingga gerak persendian tidak kaku yang mengakibatkan ayunan tungkai saat bergerak lebih lebar dan besar. Pada latihan ini juga meningkatkan keseimbangan dinamis karena pemain diharuskan dapat mengontrol keadaan tubuh saat dilakukannya pergerakan. Dengan meningkatkan komponen diatas secara otomatis kelincahan diharapkan mengalami peningkatan.

Penelitian yang dilakukan oleh Pratama (2018) ladder drill dapat melatih otot-otot lower extremity diantaranya m.sartorius, $m$. semitendinosus, $m$. gracilis, $m$. glut maximus, $m$. vastus lateralis, $m$. vastus medianus, $m$. vastus intermedius, $m$. gastrocnemius, $m$. peroneus longus, m.extensor hallucis longus dan $m$. flexor halucis longus yang dimana otot tesebut merupakan otot yang berperan penting dalam kelincahan.

Setelah dilakukan penelitian kemudian dilakukan uji perbandinga mann whitney yang mendapatkann hasil bahwa tidak terdapat perbandingan efektifitas shuttle run dan ladder drill exercise terhadap kelincahan. Kedua latihan tersebut sama-sama memiliki pengaruh untuk meningkatkan kelincahan akan tetapi tidak ada perbandingan efektifitas yang signifikan diantara kedua latihan tersebut. Kelincahan bukanlah sebuah komponen fisik yang hanya terdiri dari sebuah penyusun, melainkan tersusun dari beberapa komponen diantaranya kekuatan, kecepatan, koordinasi, waktu reaksi dan power (Sari, 2019). Kelincahan yang merupakan salah satu bagian komponen wajib dimiliki oleh para pemain futsal dikarenakan dalam bermain futsal, pemain dituntut gesit dalam melakukan pergerakan sambil menjaga keseimbanagn tubuhnya. Perubahan arah dan kecepatan secara sigap dapat memungkinkan para pemain untuk menghindar bahkan mengalahkan lawannya saat bermain.

Selain itu dalam kedua latihan tersebut dapat sama sama memicu peningkatan adaptasi dari reaction time seorang pemain. Dimana saat melakukan latihan tersebut dalam jangka waktu yang lama pemain akan mendapatkan adaptasi yang awalnya sebelum diberikan latihan reaction time seorang pemain akan lambat kemudian seiring diberikan latihan rutin reaction time seorang pemain akan meningkat karena selama latihan pemain mendapatkan rangsangan secara terus 
menerus. Stimulasi yang disalurkan akan cepat ditangkap otak dan disalurkan menjadi gerakan dimana dalam latihan tersebut sama sama melatih reaksi untuk mengubah gerakan secara cepat yang merupakan komponen kelincahan maka dari itu tidak ada perbedaan dalam meningkatkan kelincahan (Toho, 2020)

Kedua latihan sama sama mengandalkan kecepatan gerak kaki dimana banyak melibatkan otot tungkai sebagai penggerak utamanaya. Sehingga kedua latihan tersebut sama sama banyak memicu adaptasi terhadap kontrol gerakan otot selama melakukan gerakan secara cepat yang akan menyebabkan diameter myofibril otot akan lebih tebal dan cenderung elastis (Ardika, 2015)

Penelitian yang dilakukan oleh Anwar (2019) yang membandingkan antara dua buah latihan yaitu latihan shuttle run dan latihan ladder drill untuk melihat nilai kelincahan pemain basket Bosowa Internastional School menyebutkan ladder drill membantu untuk melatih singkronisasi supaya dapat melakukan gerakan secara cepat dan seimbang. Latihan tersebut dapat membantu membantu agar kaki dapat bergerak dengan cepat. Itu dikarenakan selama latihan yang progresif akan membantu otot dalam beradaptasi saat menierima beban latihan yang berat yang mengakibatkan kelincahan kaki beratambah. Kemudian latihan shuttle run secara teratur dapat mempercepat kontraksi otot dan mampu meningkatkan kontrol keseimbangan saat berbelok. Kedua latihan ini dapat memberikan efek positif dalam adaptasi jangka panjang pada serat otot yang memungkinkan respon gerakan yang lebih baik dan efisien sesuai kebutuhan. Selain itu akan terjadi adaptasi secara natural kepada kemampuan untuk mempercerpat rangsangan pengiriman impuls di sistim saraf pusat hingga terjadi gerakan.

Kedua latihat tersrebut dapat meningkatkan LGS yang dimana saat latihan tersebut terjadi kontraksi eksentrik dan konsentrik yang dimana kontraksi eksentrik sendiri menyebabkan penambahan fleksibilitas pada otot tungkai. Pada saat fleksibilitas meningkat kelincahan akan meningkat (Trisnowiyanto, 2016)

\section{KESIMPULAN}

Berdasarkan hasil penelitian dan pembahasan didapatkan hasil bahwa shuttle run exercise dan ladder drill exercise memiliki pengaruh terhadap peningkatan kelincahan. Namun saat dibandingkan kedua latihan tersebut tidak terdapat perbedaan yang signifikan mana yang lebih efektif antara shuttle run exercise dan ladder drill exercise

\section{REFERENCES}

Anwar, R. J., \& Sutono, E. (2020). Influence of Ladder Drill Exercises and Shuttle Run Toward Agility Level Among Basketball Players in Bosowa International School Makassar. In Journal of Physics: Conference Series

Ardika, I. M. Y., Kanca, I. N., Sudarmada, I. N., \& Or, S. (2015). Pengaruh Circuit Training Terhadap Kelincahan dan Daya Ledak Otot Tungkai. Jurnal Ilmu Keolahragaan Undiksha, 3(1).

Baruna, Arys Hasta. (2018). Perbedaan Pengaruh Zig-Zag Run Exercise Dan Shuttle Run Exercise Terhadap Peningkatan Agility pada Pemain Sepakbola di SSB Gajayana Malang. Skripsi, Universitas Muhammadiyah Malang.

Chandrakumar, N., \& Ramesh, C. (2015). Effect of ladder drill and SAQ training on speed and agility among sports club badminton players. International Journal of Applied Research, 1(12), 527-529.

Dewi, Anita, R., Prihatanta, Hadwi. (2015). Hubungan Berat Badan dan 
Tinggi Badan Terhadap Kelincahan Pemain Futsal Putri UNY. Jurnal Olahraga 16(2).

Hadi, Firdaus, et al. (2016). Pengaruh Latihan Ladder Drills Terhadap Peningkatan Kelincahan Siswa U17 Di Persatuan Sepakbola Jajag Kabupaten Banyuwangi. Jurnal Pendidikan Jasmani Universitasn Negeri Malang. 26(1).

Kusnanik, N dan Been Rattray. (2017). Effect Of Ladder Speed Run and Repetated Sprint Ability In Improving Agility and Speed Of Junior Soccer Player. Journal Acta Kinesiologica (11)

Mashud, M., \& Karnadi, M. (2016). Optimalisasi Kelincahan Pemain Futsal Pra Pon Kalimantan Selatan Melalui Latihan Ladder Drill. Multilateral Jurnal Pendidikan Jasmani dan Olahraga, 14(1).

Meng, H. C., \& Lee, J. L. F. (2014). Effects of Agility Ladder Drills on Dynamic Balance of Children. Jurnal Sains Sukan dan Pendidikan Jasmani, 3(1), 68-74

Pratama T., Budiawan M., Sudarmada. (2014). Pengaruh pelatihan three corner drill terhadap kelincahan dan power. Singaraja : E-Journal Universitas Pendidikan Ganesha Jurusan Ilmu Keolahragaan

Putra, Galant Pradana. (2013). Profil Kondisi Fisik Pemain Futsal Pelatihan Daerah (PELATDA) Kabupaten Klaten Tahun 2013. Yogyakarta: Universitas Negeri Yogyakarta

Rahman, F. J. (2018). Peningkatan Daya Tahan, Kelincahan, dan Kecepatan pada Pemain Futsal: Studi Eksperimen Metode Circuit Training. Jurnal SPORTIF: Jurnal Penelitian Pembelajaran,4(2), 264-279.
Rakhmawati, Aisyah. (2019). Pengaruh Kombinasi Shuttle Run dan Bounce And catch Reaction Ball Terhadap Peningkatan Agility Usia 10-12 Tahun di MI maarif Pademonorogo. Skripsi: Universitas Muhammadiyah Malang

Taghinejad, S. (2013). Relationship between anthropometric measures (weight, height, body mass index) with some elements of physical fitness (agility, speed, balance) in girls ages 12 to 14 (Doctoral dissertation, Master thesis, Islamic Azad University).

Toho, Cholik Mutohir, dkk. (2011). Berkarakter Dengan Bangsa Berolahraga Dengan Berkarakter. Surabaya. SPORT Media

Tollison T. (2011). Modern Stretching. Exercise and Sport Science University of Utah. 1-25

Untoro, F. S., \& Kurniawati, D. (2017). Hubungan Antara Indeks Massa Tubuh Dengan Kelincahan Dan Volume Oksigen Maksimum Pada Pemain Futsal MUFC Karanganyar (Doctoral dissertation Universitas Muhammadiyah Surakarta).

Womsiwor, Daniel dan I Nengah Sandi. (2014). Pelatihan Lari Sircuit Haluan Kiri Lebih Baik Dari Pada Haluan Kanan Untuk Meningkatkan Kelincahan Pemain Sepakbola Siswa SMK X Denpasar. Sport and Fitnes Journal, 2(1), 10-17. 